\title{
Anti-ds DNA Levels and C3 and C4 Complement Levels in Suspected Flare Up of Systemic Lupus Erythematosus Patients Attending a Tertiary Care Hospital
}

\author{
Ananthakrishnan Parthasarathy and Meenakshi Subramanian*
}

\author{
Institute of Rheumatology, Madras Medical College, The Tamilnadu Dr. MGR Medical \\ University, Tamilnadu, India \\ *Corresponding author
}

\begin{abstract}
A B S T R A C T
Keywords

Systemic lupus erythematosus (SLE)

\section{Article Info}

Accepted:

12 February 2019

Available Online:

10 March 2019

Systemic lupus erythematosus (SLE) is a multisystemic autoimmune disease with a variable clinical course and a wide range of organ manifestations. 101 Blood samples were tested for both anti-dsDNA and Complement levels in patients satisfying the 1982 American College of Rheumatology (ACR) criteria (updated in 1997) for SLE with suspected clinical flares using Euroimmun ELISA Anti-ds DNA-NcX ELISA (IgG) kit and by Nephelometry using the Nephstar kit for both the complements C3 and C4. In majority of patients Anti ds DNA, C3 and C4 levels were normal and almost same number of patients had Anti ds DNA, C3 were increased with decreased C4 levels. The high index of clinical suspicion and concurrent laboratory estimation of Anti ds DNA, C3 and C4 levels will help the clinician in the diagnosis and initiation of proper treatment of SLE and its flare ups.
\end{abstract}

\section{Introduction}

The criteria of the American College of Rheumatology (ACR), first published in 1982 and later revised in 1997, for the diagnosis of SLE has the immunologic criteria as follows: (Aletaha D 2010 et al.,) a. Anti-dsDNA: in abnormal titre, orb. Anti-Sm: presence or absence of anti Smantibody orc. Presence of antiphospholipid antibodies detected as:(1) an increased concentration of $\operatorname{IgG}$ or $\operatorname{IgM}$ anticardiolipin (ACL) antibodies, (2) a positive test for lupus anticoagulant using a standard method, or(3) a false positive serologic test for syphilis known to be positive for at least 6 months and confirmed by the more specific Treponema pallidum immobilisation (TPI) or fluorescent treponemal antibody absorption (FTA-ABS) test, d.an abnormal titre of antinuclear antibody by immunofluorescence (IF) or other methods at any point in time and in the absence of drugs known to be associated with 'drug-induced lupus' syndrome. Application of the ACR criteria without analysis of autoantibodies may result in an increased 
estimation of the disease. The Systemic Lupus International Collaborating Clinics (SLICC) Classification Criteria includes: 1. Increased ANA levels2. Anti-dsDNA antibodies. 2. Anti-Sm antibodies, 3. Antiphospholipid antibodies (ACL and anti- $\beta 2$-glycoprotein1 [IgA, IgGor IgM- $\beta 2 \mathrm{GP} 1]$ antibodies; falsepositive VDRL [Venereal Disease Research Laboratory] test), 4. Low complement (C3, C4, or CH50), 4. Positive Direct Coomb's test (in the absence of hemolyticanemia). Based on these criteria, we tried to correlate the levels of dsDNA and complement in SLE patients registered in our hospital as per ACR classification criteria.

Antibodies to DNA may be: 1 . those that react to single-stranded DNA and 2.those that react to double-stranded DNA (dsDNA). Among these, anti-dsDNA antibodies are relatively specific (95\%) for SLE, making them useful for diagnosis 11and are involved in the pathogenesis of this disease by forming complexes with DNA thus forming a close relationship between the course of the disease and serum anti-dsDNA profiles which suggests the possibility of antids DNA profiles as prognostic and therapeutic guides (Kavanaugh AF et al., 2002) A negative test does not exclude the disease, because antidsDNA antibodies occur only in $30 \%$ of patients with SLE (Gary s et al., 2016). Serum complement levels are frequently used as a prognostic indicator and as a diagnostic aid. In previous studies Linnik et al., 2015), the combination of hypocomplementemia and high levels of antibodies to dsDNA was always accompanied by active SLE, especially nephritis.

The same correlation was found in patients with hypocomplementemia and elevated titres of dsDNA antibody and the occurrence of renal involvement. Complement testing is not for screening but is routinely used to monitor disease activity in SLE patients. An SLE flare will result in decreased complement levels and an elevated complement level is a nonspecific finding with no clinical relevance. In a retrospective study of 91 patients with systemic lupus erythematosus (SLE) enrolled in our Hospital, the relation between antidsDNA levels and serum levels of complement components - C4 and C3 weretested in our Immunology laboratory were analysed.

\section{Materials and Methods}

This was a retrospective study conducted in the Immunology Laboratory of Institute of Rheumatology, Madras Medical College \& Rajiv Gandhi Govt. General Hospital, Chennai from $1^{\text {st }}$ August 2018 to $31^{\text {st }}$ January 2019. Blood samples were tested for both antidsDNA and Complement levels in patients satisfying the 1982 American College of Rheumatology (ACR) criteria (updated in 1997) for SLE with suspected clinical flares. Samples of patients below 16 years and pregnant women were excluded from the study. We used EUROIMMUN ELISA Antids DNA-NcX ELISA (IgG) kit for analysing Anti-dsDNAsemi quantitatively using automated ELISA machines and the former recommended normal interpretation values as $<100 \mathrm{IU} / \mathrm{ml}$ - negative, $\geq 100 \mathrm{IU} / \mathrm{ml}$-positive (Elisa A). Complement levels were analysed by NEPHELOMETRY using the NEPHSTAR kit for both the complementsC3 and $\mathrm{C} 4$. Normal ranges of $\mathrm{C} 3$ and $\mathrm{C} 4$ in a healthy adult is: $0.9-1.8 \mathrm{~g} / \mathrm{L}$ and $0.1-0.4 \mathrm{~g} / \mathrm{L}$ respectively. (Lachmann et al., 1973)Both these tests were performed after necessary calibration and validation according the kit instructions. Of the 101 samples received tests for anti dsDNA and complement levels were performed and the results were analysed and tabulated.

\section{Results and Discussion}

All 101 samples that we received from our Rheumatology OPD are with clinical suspicion of flare of SLE. Out of 101 samples 
tested and analysed - anti ds DNA, C3 and C4 levels were found to be normal in 33 samples, in 13 samples anti-ds DNA was only elevated whereas $\mathrm{C} 3$ and $\mathrm{C} 4$ were within normal levels. In 30samples we observed that anti ds DNA levels were increased and both $\mathrm{C} 3$ and $\mathrm{C} 4$ levels were reduced. In 8 samples, anti ds DNA levels are normal, but C3 and C4 levels are decreased. 15 samples showed increase in anti dsDNA and decrease in C3 levels but C4 levels are normal. In 2 samples anti ds DNA levels are increased and C3 levels are normal, but $\mathrm{C} 4$ levels are decreased.

Serial measurement of anti-dsDNA antibody levels was more sensitive for predicting exacerbations than was measurement of C3 and or $\mathrm{C} 4$ levels $(\mathrm{P}<0.03)$. Serial assessment of anti-dsDNA antibody levels, especially by the Farr assay, is a sensitive and reasonably specific method for predicting disease exacerbations in SLE (Ter Borg et al., 1990).

Serological tests are commonly used to assess the disease activity and predict lupus flare. During active disease, usually there is a fall in complement levels and a rise in anti-double stranded deoxyribonucleic acid (anti dsDNA) levels. Our study showed almost similar results. Literature suggests strong correlation between disease activity and a rise in dsDNA and fall in complement (C3 and C4) levels. However it may not be true in all patients. Studying correlation between SLEDAI, antidsDNA, C3 and C4 in different clinical subsets of SLE during disease flare and in remission will be useful (Narayanan $\mathrm{K}$ et al., 2010).

Elevated anti-dsDNA antibodies and hypocomplementemia do not occur in all patients and their correlation with disease activity is not absolute. Patients can have persistently elevated antidsDNA antibody titers without evidence of clinical disease for several months (Gladman et al., 1979). The anti dsDNA antibody titer was more sensitive than serum C3 or C4 levels in predicting exacerbations (Swaak et al., 1979) studies have proposed that qualitative properties of the antidsDNA antibodies, such as the complement fixing property, avidity, dissociation constant and immunoglobulin class are more important determinants than the total antibody content in regard to pathogenicity and correlation with disease activity (Esdaile et al., 1996) Our study will help the clinician to correlate clinical response to treatment and flare ups when suspected.

Anti-DNA testing can be very useful for the diagnosis of SLE. Whereas a positive test for anti-DNA offers strong support for the diagnosis of SLE, a negative test result does not exclude the diagnosis. Anti-DNA testing should be reserved for patients who have a positive ANA.

Anti-DNA antibodies do correlate with overall disease activity in SLE. However, as the correlations are at best modest, test results must be interpreted in the overall clinical context. Similarly, anti-DNA antibodies correlate with the activity of renal disease in SLE, but to a limited extent. Higher titers of anti-DNA have a stronger association with disease activity. ${ }^{(2)}$ Hence our analysis test results must be taken in to consideration with the patients' clinical condition at that moment and applied for treatment accordingly.

The analyses specifically establish that reductions in anti-dsDNA antibodies are associated with a reduced risk of renal flare and an increase in C3 levels inpatients with SLE who have a history of renal disease.

Patients with SLE who have reductions in anti-dsDNA antibody levels are more likely to have a favorable clinical prognosis than are patients with stable or increasing anti-dsDNA antibody levels (Fig. 1 and Table 1). ${ }^{(4)}$ 
Table.1

\begin{tabular}{|c|c|c|c|c|c|}
\hline $\begin{array}{c}\text { Anti ds DNA } \\
\text { Normal C3 } \\
\text { and C4 } \\
\text { Normal }\end{array}$ & $\begin{array}{c}\text { Anti ds DNA } \\
\text { Increased C3 and } \\
\text { C4 Normal }\end{array}$ & $\begin{array}{c}\text { Anti ds DNA } \\
\text { Increased C3 and } \\
\text { C4 decreased }\end{array}$ & $\begin{array}{c}\text { Anti ds DNA } \\
\text { Normal C3 } \\
\text { and C4 } \\
\text { Decreased }\end{array}$ & $\begin{array}{c}\text { Anti ds DNA } \\
\text { Increased C3 } \\
\text { decreased and } \\
\text { C4 Normal }\end{array}$ & $\begin{array}{c}\text { Anti ds DNA } \\
\text { Increased C3 } \\
\text { Normal and C4 } \\
\text { Decreased }\end{array}$ \\
\hline $\mathbf{3 3}$ & 13 & 30 & 8 & 15 & 2 \\
\hline
\end{tabular}

Fig.1

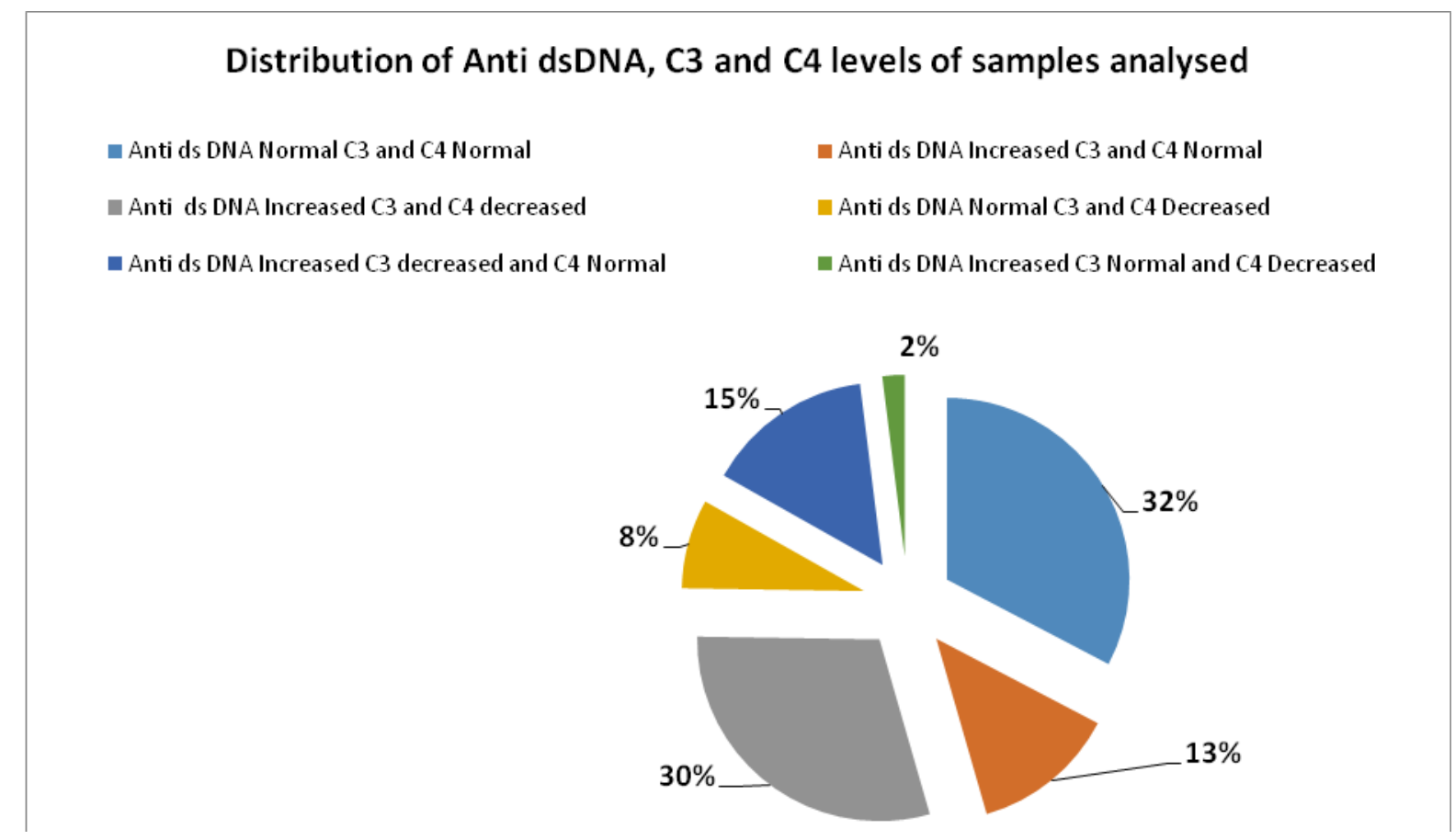

In conclusion, in our retrospective observational study we have analysed 101 samples that we received from our Rheumatology OPD from the patients with clinical suspicion of flare of SLE. With the results of Anti ds DNA, C3 and C4 levels that we observed after careful analysis showed that in majority of patients Anti ds DNA, C3 and $\mathrm{C} 4$ levels were normal and almost same number of patients had Anti ds DNA, C3 were increased with decreased $\mathrm{C} 4$ levels. The high index of clinical suspicion and concurrent laboratory estimation of Anti ds DNA, C3 and C4 levels will help the clinician in the diagnosis and initiation of proper treatment of SLE and its flare ups. Also it is important to include tests for qualitative properties of Anti ds DNA in the future prospective study. With respect to flare ups in cases of specific organ involvement require much larger prospective study with patients on treatment for SLE with periodic follow up for involvement of other organ.

\section{References}

Aletaha D, Neogi T, Silman AJ, Funovits J, Felson DT, Bingham CO, et al., 2010 Rheumatoid arthritis classification criteria: An American College of Rheumatology/European League Against Rheumatism collaborative initiative. Vol. 62, Arthritis and Rheumatism. 2010. p. 2569-81. 
Complement 3 (C3) Kit. :11-2.

Complement 4 (C4) Kit 16. 2 Lachmann, P. J., Hobart, M. J. and Ashton, W. P. (1973) in Handbook of Experimental Immunology, 2nd Ed., 16, Ed. D. M. Weir, Blackwell Scientific. :3-4.

Elisa A. Anti-dsDNA-NcX ELISA (IgG) Anti-dsDNA-NcX ELISA (IgG). Gary S.

Esdaile JM, Joseph L, Abrahamowicz M, Li Y, Danoff D, Clarke AE. Routine immunologic tests in systemic lupus erythematosus: is there a need for more studies? J Rheumatol. 1996 Nov; 23(11): 1891-6.

Firestein, Ralph Budd, Sherine E Gabriel, Iain B. McInnes JRO. Kelley and Firestein's Textbook of Rheumatology. 10TH ed. Elsevier Health Sciences, 2016;

Gladman DD, Urowitz MB, Keystone EC. Serologically active clinically quiescent systemic lupus erythematosus: a discordance between clinical and serologic features. Am J Med. 1979 Feb; 66(2): 210-5.

Kavanaugh AF, Solomon DH. Guidelines for immunologic laboratory testing in the rheumatic diseases: Anti-DNA antibody tests. Arthritis Rheum. 2002;47(5):546-
55

Linnik MD, Hu JZ, Heilbrunn KR, Strand V, Hurley FL, Joh T, et al., Relationship between anti-double-stranded DNA antibodies and exacerbation of renal disease in patients with systemic lupus erythematosus. Arthritis Rheum. 2005; 52(4): 1129-37.

Narayanan K, Marwaha V, Shanmuganandan CK, Shankar S. Correlation between systemic lupus erythematosus disease activity index, C3, C4 and anti-dsDNA antibodies. Med J Armed Forces India [Internet]. 2010;66(2):102-7. Available from: http://dx.doi.org/10.1016/S03771237(10)80118-2

Ter Borg EJ, Horst G, Hummel EJ, Limburg PC, Kallenberg CGM. Measurement of increases in anti-double-stranded dna antibody levels as a predictor of disease exacerbation in systemic lupus erythematosus. Arthritis Rheum. 1990; 33(5): 634-43.

Swaak AJ, Aarden LA, Statius van Eps LW, Feltkamp TE. Anti-dsDNA and complement profiles as prognostic guides in systemic lupus erythematosus. Arthritis Rheum. 1979 Mar; 22(3): 22635 .

\section{How to cite this article:}

Ananthakrishnan Parthasarathy and Meenakshi Subramanian. 2019. Anti-ds DNA Levels and C3 and C4 Complement Levels in Suspected Flare Up of Systemic Lupus Erythematosus Patients Attending a Tertiary Care Hospital. Int.J.Curr.Microbiol.App.Sci. 8(03): 1587-1591. doi: https://doi.org/10.20546/ijcmas.2019.803.184 